\title{
THE INTERNATIONAL UNION FOR THE CONSERVATION OF NATURE AND NATURAL RESOURCES
}

\author{
Fiftir Genenat، Assenibly \\ Excursions
}

By A. M. V. BoyLe

Hydro-electric schemes and their effect on landscape and habitat loom large in the view of nature conservators to-day. During the latest meeting of the International Union for the Conservation of Nature at Edinburgh in June, 1956, those attending were able to see something of the work of the North of Scotland Hydro-Electric Board, and to judge for themselves its effect on the countryside.

The Pitlochry dam, the first to be visited, is part of the Tummel Valley Development Scheme and is deservedly something of a showpiece in modern hydro-electric work. The dam and power house, built of stone to harmonize with their surroundings, are remarkably unobtrusive as one comes upon them bridging the narrow, wooded valley of the Tummel. We saw the fish-pass which enables the salmon to come up and the electronic counter which records their passagc. Bencath are the underwater inspection chambers. where the fish can be watched as in an aquarium.

The dam has formed a new loch, Loch Faskally, a narrow winding sheet of water which certainly cannot be said to spoil the landscape. After walking through woods of fine conifers with banks of rhododendron ponticum in full bloom, we came to Faskally House, which is now a Foresters' 'Training School, on the shores of the new loch. Nearby is the Trout Resenrch Laboratory of the Fisherics Division, Scottish Home Department, which collaborates with the Hydro Board. Grent efforts have been made to fit all these works into the landseape. 'The pipes bringing water to the power station from higher ground have been buried wherever possible and in other places have been painted green, many shades having been tried out before the most suitable was found. 'The variation in water level in the reservoir lochs is narrowly controlled so as to avoid leaving exposed mud.

We drove along the north side of Loch Tummel and had a beautiful view of the mountains of Brendalbane and in particular the unmistakable cone of Schichallion, which dominates the 
eastern end of Loch Rannoch. This famous Queen's Vicw has not been spoilt by the raising of the level of Loch Tummel.

In the afternoon we had an exciting drive up Glen Iyon, which is in the Breadalbane Catchment Area. The road is narrow and the large buses had to be very agile, especially when mecting the Hydro Board's loaded lorries. The lower part of Glen Lyon has delightful wooded gorges, but higher up the valley is bare, with smooth short-cropped green hills. Up here two dams are being built and at the moment the scene is chaotic, as one would expect with a major building project. However, when the work is finished and the valley tidied up, as has been done in other places, it is hard to think that the bare glen may not be improved by the small lochs which will result.

All this is on the credit side. On the other. hand it must be said that lines of pylons do not improve the view, although in many cases care has been taken to keep them off the skyline. After secing more and more power stations one is inclined to say "What, another?" however carefully they have been planned. One point does stand out very clearly, however ; this is that carcful planning and co-operation between hydro-clectric boards and those concerned with conscrvation of natural benuty, can work wonders. The flooding of small areas and the raising of water levels by a few feet rather than wholesale inundation of a beautiful district; the extra trouble in tunnelling the water underground instead of running unsightly pipelines down the hillsides; all these things are of inestimable value.

\section{Brinn Eigite}

After the conference we divided into several parties for the long excursions, ours being to the north-west to visit the Beinn Eighe Nature Reserve in Wester Ross. On the first day we drove west from Edinburgh to Stirling through the industrial and mining areas around Falkirk, passing some of the lugge shale bings, the refuse dumps of the shale oil industry. After Stirling, with its castle on a rock overlooking the town, we continued west and saw some of the relict raised bogs of Flanders Moss. This area, the Carse of Stirling, is composed of estuarine clnys of a twenty-five foot raised beach. Many geese visit it in winter. 'lurning north through Callander, we passed young forestry plantations in Strathyre, the first of many we were to sec.

Beyond 'Iyndrum the country gets wilder and more bare and there are a few groups of relict pines near Loch 'Tulla. After that we crossed Rnnnoch Moor, a wide expanse of drying-out blanket bog at just below 1,000 fect; it is a desolate place and 
a fitting prelude to the cntrance of Glen Coc. 'The low clouds swirling round the massive rocky mountain tops and the grim historical associations combine to make Glen Coe an impressively forbidding place. On Loch Leven, opposite the mouth of the glen, is an island which was used by the MacDonalds as a burying ground in the days when graves had to be protected from wolves. At the head of Loch Leven are the ugly works of the British Aluminium Company. We spent the night at Fort William at the south-west end of Glen More.

On the second day we drove up the Great Glen and along the shore of Loch Ness. Stopping at Castle Urquhart we scanned the still water for a sign of the Monster, but he had not the good sense to appear to such a distinguished gathering from the world of nature conservation. The Castle is an interesting ruin, the oldest part dating from the days when the early saints travelled from the western isles to preach Christianity in the east. We went up Glen Urquhart to Glen Affric, the subject of much controversy over its hydro-electric scheme, and famous for its beauty, its wonderful forest of native Scots pine and magnificent birches. After a brief visit to the dam, one must I think admit that no dam could be less obtrusive, if dam there had to be.

The route westwards through Strath Bran to Achnasheen is remarkable for its desolation. During the last war whole areas were clear-felled, leaving a mass of tree stumps. The picture of the bare, croding hillsides is all the worse when one realizes that at one time many of the valleys of the north-west held onk woods, with conifers up to the tree line. Deforestation started as far back as the years 800 to 900 A.D. and has gone on steadily ever since. Now the Forestry Commission is doing its best to replant with blocks of conifers, but we saw no attempt to replant valley bottoms with oak. 'The dense, regimented plantations of conifers are not everyone's choice, but after' sceing what the Commission is up against one has more sympathy for their work.

After passing Achnasheen, where there are good examples of glacial lake terraces, we spent two nights at Kinlochewe at the head of Loch Marec, and close beside the Beinn Eighe Rescrve. 'This reserve of about sixtecn square miles, was the first National Nature Reserve to be established in Britain, and was declared in 1951. It consists of mountain, moorland and woodland, cxtending from fifty to $3,200 \mathrm{ft}$., the rock being mainly Cambrian quartzite and Pre-Cambrian 'Torridonian sandstone. These rocks produce very poor soils and scanty vegetation except where thin bands of Cambrinn dolomite and mudstone result in local patches of very rich soil. 'The old pine wood on the 
lower slopes, above Loch Maree, is a relic of the aboriginal Scots pine forest. It still maintains itself by natural seeding, but ecological research is being carried out on the establishment of Scots pine on the moor area. Dr. MeVean, the scientific officer, showed us how he had been encouraging the wood to spread by sowing pine seeds; some of the seedlings were already several inches high. While we listened to his account of the experiment, we looked up to see a herd of red decr moving across the bare slopes below the rocky outcrop.

For us the most exciting moment was when we saw a pine marten in a small wood just outside the reserve. It was intent on digging out a wasps' nest at the foot of a tree and cvery now and again sat up and looked towards us. It was a lovely creature with dark brown fur; long bushy tail and yellow-tipped cars. After a number of people had collected to watch, it could bear it no longer, and bounded away across the ground to disappear in a hole in the rocks. The pine marten is very seldom seen, even by the local Nature Conservancy staff, but quite a number exist in the area and a study of the animal's excreta is being made which shows it to be omnivorous. 'Two large birds circling in the mountains were probably golden eagles; many whinchats were breeding and a large fox crossed our path one morning.

After a fine tea at Anancaun Field Station, provided by the Warden's wife, we drove west to the coast and up to Gairloch, and to the National Trust gardens at Inverewe. It would take too long to describe the gardens, but they show what can be done to transform a bare headland of 'lorridonian sandstone into a trec-sheltered garden full of plants and shrubs from places as far apart as Chile, the Himalayas and New Zcaland.

The return journey on the fourth day took us to Inverness and then south-east to Nethy Bridge on the fringe of the Cairngorms. This drive again showed a desolate landscape, victim of clear-felling and burning, but with forestry plantations starting in many places.

On the last day we spent the morning at Loch an Eilean in the Cairngorms Nature Reserve, the largest reserve in Britain, about sixty square miles in area. The benutiful loch lies in a setting of fine old Scots pine and on the small island was onc of the last nesting places in Scotland of the osprey. We were lucky enough during our short visit to see crested tits in the woods along the shore and a black-thronted diver on the loch.

'That was our last call on this interesting tour, and we returned by the main road through Perth and ancross the Forth by the Kincardine Bridge to Edinburgh. 


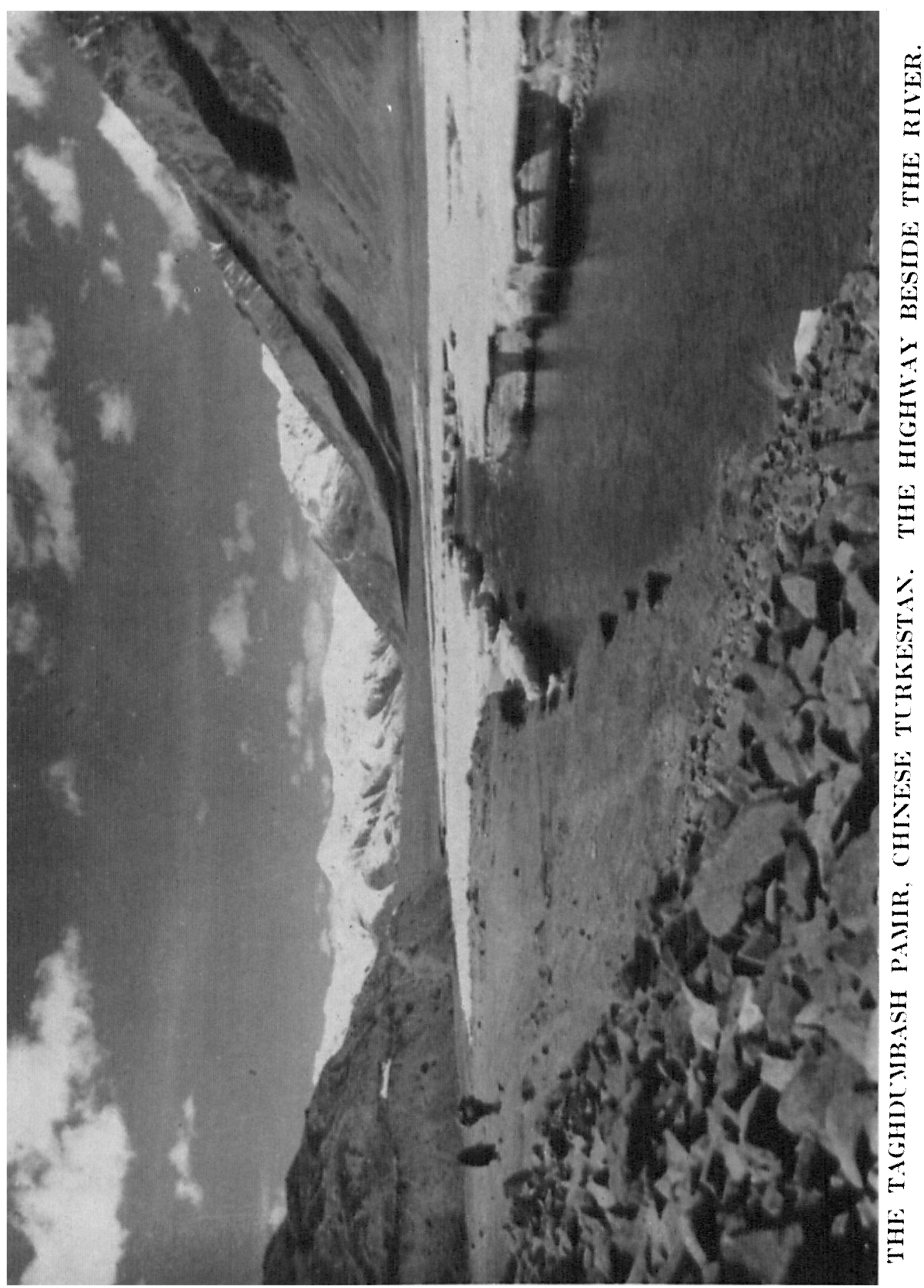




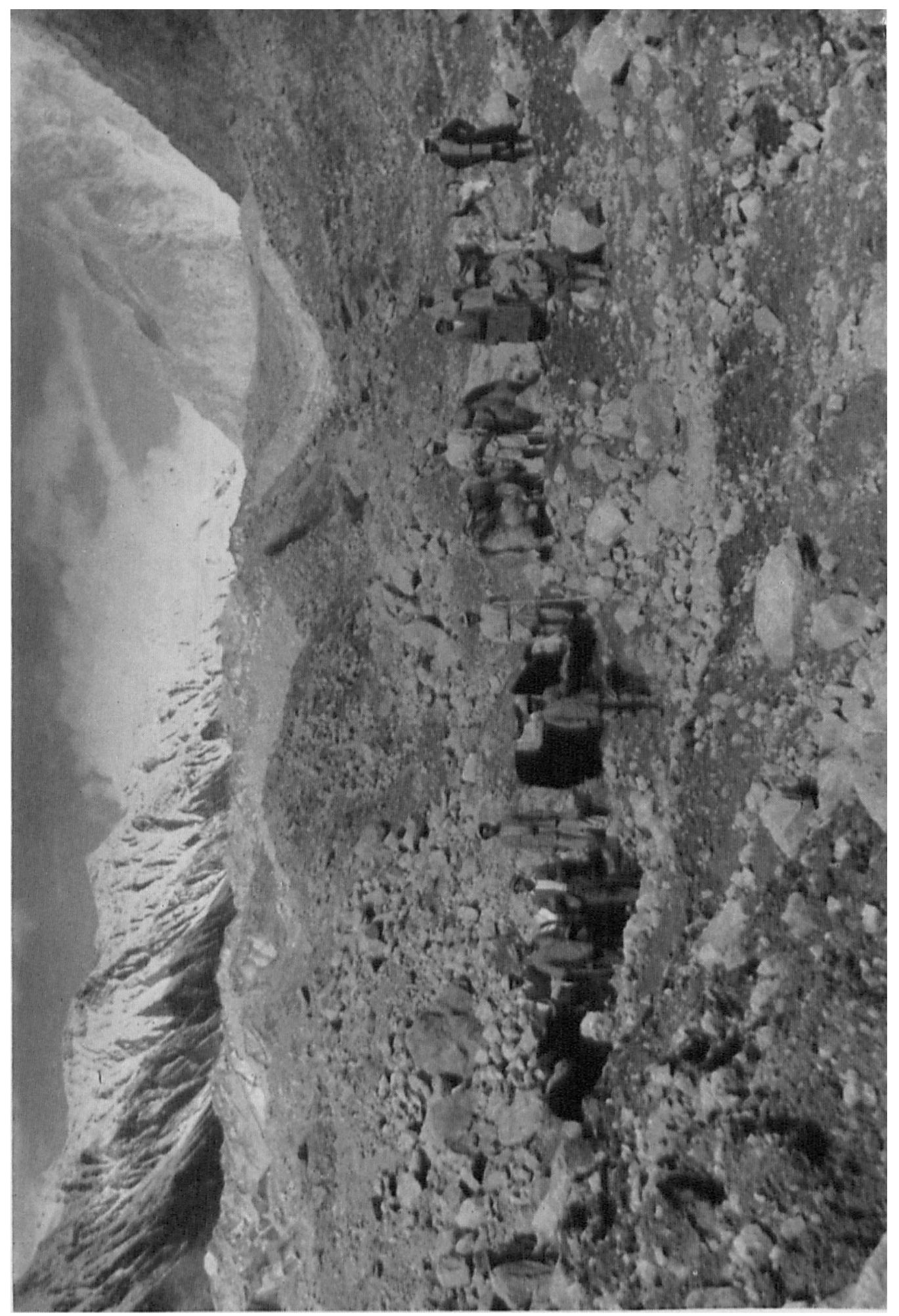

ن 